\title{
Chan Buddhism during the Times of Yixuan and Hsing Yun:
}

\author{
Applying Chinese Chan Principles to Contemporary Society
}

\section{SHI Juewei}

Linji Yixuan 臨濟義玄 (d. 866) and Fo Guang Hsing Yun 佛光星雲 ${ }^{1)}$ (1927-), although separated by more than a millennium, innovatively applied Chan teachings to the societies in which they lived to help their devotees discover their humanity and transcend their existential conditions. Both religious leaders not only survived persecution, but brought their faiths to greater heights. This paper studies how these masters adapted Chan Buddhist teachings to the woes and conditions of their times. In particular, I shall review how Yixuan and Hsing Yun adapted the teachings of their predecessors, added value to the socio-political milieu of their times, and used familiar language to reconcile reality and their beliefs.

\section{Background}

These two Chan masters were selected because of the significance of their contributions. Linji Yixuan was not only the founder of a popular Linji ${ }^{2)}$ school in Chan Buddhism but was also posthumously awarded the title of Meditation Master of Wisdom Illumination (Huizhao Chanshi 慧照禪師) (Sasaki and Kirchner 2009, 52) by Emperor Yizong 懿宗 of the Tang dynasty (r. 859-873). Hsing Yun, a very strong proponent of Humanistic Buddhism, is currently the recipient of 15 honorary doctorate degrees from universities around the world (Shi and Weng 2015). To have received such accolades, both Chan masters ought to have made momentous contribution to their societies.

Although Yixuan and Hsing Yun had humble beginnings, they were well-grounded in Buddhist teachings. Yixuan was well-versed with Huayan 華嚴 and Weishi 唯識 teachings (Sasaki and Kirchner 2009, 66) while Hsing Yun received a comprehensive 
education at various Buddhist seminaries in China (Gill and Michon 2012). Yixuan began his Dharma propagation activities after he settled in Linji yuan 臨濟院, a small temple in Zhenzhou 鑥州 on the invitation of an influential “man of Zhao" (Zhaoren 趙 人) (Sasaki and Kirchner 2009, 69). His career as a Chan teacher was only for about a decade but his vivid, innovative, and forceful teachings were recorded for posterity by his disciples (Sasaki and Kirchner 2009, 72). On a similar note, Hsing Yun also started his Dharma activities from a small temple in Taiwan's Leiyin si 雷音寺 in Yilan 宜蘭 on the invitation of Li Juehe 李決和 (Fu 2000, 61). Yixuan lived through the Huichang persecution, peaking in 845, which was ordered by Emperor Wuzong 武宗 of the Tang dynasty (Sasaki and Kirchner 2009, 69). Hsing Yun survived the Chinese civil war that started in 1927 and the Japanese invasion in 1937. Undeterred by the socio-political difficulties of their times, these men appreciated the existential conditions of their compatriots. Yixuan advocated a form of Chinese humanism (Faure 1993, 243) and his teachings eventually became the cornerstone of the Linji House of the Chan School of Chinese Buddhism, with himself being the first patriarch. In addition to being the 48th lineage holder of the Linji House (Fu 2000, 249), Hsing Yun promoted Humanistic Buddhism. Both masters were deeply concerned with humanity.

\section{Linji Yixuan}

Bodhidharma (Putidamo 菩提達磨, ca. 5th-6th century), acknowledged as the founder of Chan Buddhism, was credited with the Erru sixing lun 二入四行論 (Treatise on the two entrances and four practices) (Dumoulin 2005, 306). In the last practice of the xingru 行入 (entrance of practice) outlined in this Erru sixing lun, he urged his followers to observe the six perfections according to the Dharma (Dumoulin 2005, 307), without grasping nor rejecting, opposing nor agreeing (Broughton 1999, 79). Further, Bodhidharma argued for the presence of a non-discriminating intrinsic "true nature" in all sentient beings. The identification of this "serene and inactive" true principle was known as the xingru (McRae 2004, 28).

Two hundred years later, Linji Yixuan adapted these teachings to the plight of postHuichang 會昌 persecution (about 845) and a weakening Tang dynasty. Besides growing banditry and disorder in the years between 820 and 860 (Welter 2006, 8), Buddhism suffered immensely from Emperor Wuzong's decree ordering the expulsion and 
laicisation of monks, nuns and novices, seizure of their properties and confiscation of lay offerings (Weinstein 1987, 116-126). Over 40,000 Buddhist hermitages were destroyed and more than 260,000 monastics were defrocked (Weinstein 1987, 133-134). This persecution paved the way for the popularity of Chan Buddhism that did not require monasteries, images or texts in order to gain an insight into one's true nature (Weinstein 1987, 150). Yixuan's unparalleled creativity gave expression to Mahāyāna Buddhism in line with such times.

With the massive destruction of sanctuaries, sūtras and valuable objects of worship, Yixuan's teachings exemplified Bodhidharma's xingru according to the Dharma by encouraging his devotees to accept the facts of life and free themselves from the tensions between "ought" and "is" (Ives 2009, 64). To do so, Linji taught his disciples to gain insight through the here and now, rather than to search among the Buddhas and patriarchs of the past (Dumoulin 2005, 91). The theme of Linji's teachings centred on the human and his existential condition. He trained his students to live at ease in the moment, remaining simple, direct and natural; that is, without any pretence (Dumoulin $2005,193)$. Hence, his disciples were equipped to be non-contentious, conforming and accepting of circumstances. Existential liberation became possible with the acquisition of peace of mind, releasing oneself from discriminatory, and wrestling thoughts (Ives 2009, 64).

Yixuan rebuilt the confidence of people in a way not unlike Bodhidharma's xingru. Yixuan referred to everyone's true nature as "true human with no rank" (wuwei zhenren 無位眞人), a Daoist term representing the Buddha nature. According to sinologist and humanist, Paul Demiéville (1894-1979), Yixuan's interpretation was typical of Chinese humanism (Faure 1993, 243). "True human" was Daoist in origin and having "no rank" indicated marginality in hierarchical Chinese society (Dumoulin 2005, 193). Yixuan encapsulated the universal Buddha nature cleverly in familiar Daoist and Chinese terminology, hence wrapping Buddhist roots with Chinese qualities. His characteristic thundering shouts and blows aimed to shock his disciples out of hesitating doubts that they possessed the Buddha nature (or that they were none other than the Buddha) (Dumoulin 2005, 191-192).

This lively and dynamic "true human" clung to nothing and it was this transcendental state of liberation that Buddhists should aspire towards, while not 
resisting the unfortunate circumstances that befell them. By becoming one with the environment, Yixuan's disciples were not critical but rather supported the virtues of obedience, perseverance, and self-sacrifice (Ives 2009, 68). It was this sense of equanimity that formed the foundation of one's daily life and Yixuan's response to the political turmoil of the time. Yixuan freely and creatively explained Mahāyāna and Chan doctrines with insights and new methods for conveying their meaning (Sasaki and Kirchner 2009, 66, 72). Linji Yixuan left behind a legacy that was original, useful and relevant to the times.

\section{Fo Guang Hsing Yun}

Not only was Hsing Yun a dharma descendent of the Linji house of Chan Buddhism, he was also inspired by the "Buddhism in human life" (rensheng Fojiao 人生佛敎) teachings of Taixu 太虛 (1890-1947). Taixu called for a revitalisation of Buddhism globally with institutional, educational and social reforms. He promoted selfless social action to be the primary means towards acquiring spiritual insights and emphasized that wisdom into emptiness could not be attained without compassionate actions in the world (Pittman 2001, 7-8).

Hsing Yun adapted Taixu's mission to the realities of the modern era under the banner of Humanistic Buddhism (renjian Fojiao 人閒佛教). Taiwanese in the latter half of the 20th century had to cope with a rapidly expanding economy alongside encounters with a western-style liberal philosophy (Madsen 2007, 2-3). Through Humanistic Buddhism, Hsing Yun provided religious justification for Taiwanese economic expansion and an individual's upward mobility by highlighting the bodhisattva ideals (Madsen 2007, 71).

Rapid modernization brought about human alienation, among other woes. Hsing Yun demonstrated his mastery of changing situations by being completely one with the circumstances so that conscious alienation would not arise. Hsing Yun inspired his disciples by being the first to embrace new technologies. To deal with daily life, he encouraged lay devotees to adapt to the pressures and contradictions of work and family with the right attitude (Madsen 2007, 60), rather than to bemoan the situation. Hsing Yun promoted self-respect and equality, not through the individual's unalienable rights (as protected by western law) but rather through an insight into reality arising 
from proper cultivation (Madsen 2007, 78). The realization of interdependence was not left as a philosophical insight but rather was translated into social action and solidarity (Madsen 2007, 77). By serving the community with wholesome thoughts, words and actions, he suggested that a practitioner could avoid the trap of a toxic lifestyle through social fellowship and a sense of shared responsibility.

In a bustling, turbulent and chaotic society, Hsing Yun believed that Chan could ease the impetuous mind and free one from anxiety and misgivings. For example, one who embraced Chan would be unperturbed by unkind words, awkward behaviour or painful memories (Hsingyun 1992, 4-5). In addition, the philosophy of humanistic Chan was based on an undiscriminating mind that could be cultivated in daily life through the diligent practice of discipline, simplicity, gratitude, and other bodhisattva ideals (Hsingyun 2015a, 780). Lancaster aptly summed up Hsing Yun's form of Humanistic Buddhism as a recognition of suffering by not avoiding the forces of nature nor denial of realities but instead offering a means to live in the world with a full awareness of the situation (Hsingyun 2015b, ii). Hence, the liberating nature of Chan could help one deal with the intensity and fast pace of contemporary society.

Hsing Yun defined Chan as the essence of one's true nature (Hsingyun 2006, i). He encouraged his disciples to claim themselves to be the Buddha (akin to Bodhidharma's xingru). Such self-proclamation implied that individuals would re-examine themselves before succumbing to unwholesome influences prevalent in contemporary society. He helped individuals regain mental composure and recognize the inter-dependency (emptiness) of their circumstances.

Hsing Yun could justifiably be called the leader of the most vigorous, innovative and expansive Chinese Buddhist movement of the post-war generation (Pittman 2001, 273). Through education, culture, and environmental preservation as foundations of social well-being, he competently mobilised both charity and human resources for a wide program of spiritual, religious, literary and educational activities (Long 2004, 219). In accordance with the Dharma, Hsing Yun modernized a funerary Buddhism so that Buddhists could contribute productively to a growing Taiwanese economy while healing alienated individuals and creating solidarity. Humanistic Buddhism was not empty talk but was based on a genuine desire to improve people's lives (Pittman 2001, 273). The pure land of a humanistic Chan practitioner would be created by his 
willingness to perform lowly tasks out of his love for other beings and by transforming their needs into his (Pittman 2001, 274). Buddhism experienced a revival with changes in the way it was practised and perceived (Sui 2004).

\section{Conclusion}

Linji Yixuan and Fo Guang Hsing Yun combined radical innovations with the affirmation of their Chan traditions. They trained their disciples to seek transcendent meaning in a chaotic world. Both religious leaders taught their contemporaries to rediscover and have faith in human goodness and virtues. With full consciousness of the situations in which people lived, these two Chan masters restored people's confidence in themselves and contributed to the stability and growth of their societies using language that people could comprehend. The spirit of a lively Chan Buddhism was adeptly used for the benefit and recovery of their communities.

\section{Notes}

1) In the Pinyin system, the name should be expressed as Xingyun. In this paper, I use the more popular "Hsing Yun" instead.

2) Also known as Rinzai in Japan.

\section{Works Cited}

Broughton, Jeffrey L., trans. 1999. The Bodhidharma Anthology the Earliest Records of Zen. Berkeley, California: University of California Press.

Dumoulin, Heinrich. 2005. Zen Buddhism: A History. Translated by James W. Heisig and Paul Knitter. Vol. 1, India and China. Bloomington, Indiana: World Wisdom.

Faure, Bernard. 1993. Chan Insights and Oversights: An Epistemological Critique of the Chan Tradition. Princeton: Princeton University Press.

Fu, Chi-ying. 2000. Handing Down the Light: The Biography of Venerable Master Hsing Yun. Los Angeles: Hsi Lai University Press.

Gill, John, and Nathan Michon. 2012. The Life of Master Hsing Yun. Vol. 45, Buddhism in Every Step. Hacienda Heights, California: Buddha's Light Publishing. https://drive.google.com/folderview? id=0B_7tpFrDgNmpVzFpbFdYTFAtZjA\&usp=drive_web\&tid=0ByugVMWcUDBeMFgwVDVYS3RX VXM.

Hsingyun. 1992. Hsing Yun's Ch'an Talk. Translated by Yongkai and Hsinch'en. Kaohsiung: Fo Kuang Publishing House.

2006. Chan Heart, Chan Art. Translated by Pey-Rong Lee and Dana Dunlap. Hacienda Heights, California: Buddha's Light Publishing. 
2015a. 365 Days for Travellers: Wisdom from Chinese Literary and Buddhist Classics. Translated by Miaoguang. Kaohsiung: Venerable Master Hsing Yun Public Education Trust Fund.

. 2015b. Where Is the Way: Humanistic Buddhism for Everyday Life. Edited by Joyce Meadows. Los Angeles: Fo Guang Shan International Translation Centre.

Ives, Christopher. 2009. Imperial-Way Zen Ichikawa Hakugen's Critique and Lingering Questions for Buddhist Ethics. Honolulu: University of Hawai' $\mathrm{i}$ Press.

Long, Darui. 2004. "Buddhist Initiatives for Social Well-Being in Chinese History, With Special Reference to Modern Exponents of Humanistic Buddhism." Hsi Lai Journal of Humanistic Buddhism 5: 204-227.

Madsen, Richard. 2007. Democracy's Dharma: Religious Renaissance and Political Development in Taiwan. Berkeley: University of California Press.

MCRae, John R. 2004. Seeing through Zen Encounter, Transformation, and Genealogy in Chinese Chan Buddhism. Berkeley: University of California Press.

Pittman, Don A. 2001. Toward a Modern Chinese Buddhism: Taixu's Reforms. Honolulu: University of Hawai i Press.

Sasaki, Ruth Fuller, and Thomas Yūho Kirchner, trans. 2009. The Record of Linji. Honolulu: University of Hawai' i Press.

Shi, Juewei, and Stacey Weng. 2015. "Person of Significance: Hsing Yun." Buddha's Birthday Education Project: Humanistic Buddhism Resource Portal. February 18. Accessed October 22, 2015. http://www.paradeofthebuddhas.org/?page_id=5388.

Sui, C. 2004. "Meeting Taiwan's New-age Buddhists." BBC News, January 29. Accessed August 16, 2015. http://www.bbc.com/news/world-asia-25772194.

Weinstein, Stanley. 1987. Buddhism under the T'ang. Cambridge: Cambridge University Press.

Welter, Albert. 2006. Monks, Rulers, and Literati: The Political Ascendancy of Chan Buddhism. New York: Oxford University Press.

Key words religious acculturation, lively Chan, bodhisattva ideal, Buddha nature, contemporary times

(Associate Lecturer, Nan Tien Institute) 